\title{
Performance study of Non-descript, Hilly and Naked Neck indigenous chicken at fifth generation
}

\author{
S. Faruque ${ }^{1 *}$, A.K.F.H. Bhuiyan², M.O.A. Rahman ${ }^{1}$, M.S.K. Sarker ${ }^{1}$ and N.R. Sarker ${ }^{1}$ \\ ${ }^{1}$ Bangladesh Livestock Research Institute, Savar-1341, Dhaka; Department of Animal Breeding and \\ Genetics, Bangladesh Agricultural University, Mymensingh-2202
}

\begin{abstract}
The present study was conducted at Bangladesh Livestock Research Institute, Savar, Dhaka to assess the performances of three Indigenous Chicken genotypes under intensive management. A total of 1128-day-old chicks comprising of 3 types of chicken namely Naked Neck (NN), Hilly (H) and Non-descript Deshi (ND) were hatched in one batch for this study. Significant $(p<0.001)$ body weight differences among the genotypes were observed at 12th and 16th weeks of age, with the highest body weight observed for $\mathrm{H}$ genotype (1250.71 \pm 27.71 , and $1502.54 \pm 36.81 \mathrm{~g})$ among the other two genotypes. NN genotype (2.85\%) had significantly higher chick mortality than ND $(0.68 \%)$ and H $(2.08 \%)$ genotypes at $0-8$ weeks of age. The age at first egg laid was significantly $(\mathrm{p}<0.001)$ affected by genotype. The age at which Indigenous Chickens start laying eggs ranged from 152.79 to 161.95 days. The Hen-day egg production $(\mathrm{HDEP} \%)$ observed in the present study were affected significantly $(\mathrm{p}<0.001)$ by genotype. In this study, the average $\mathrm{HDEP} \%$ of ND, $\mathrm{H}$ and $\mathrm{NN}$ were found to be $38.44 \pm 2.18,30.43 \pm 2.10$ and 41.95 \pm 2.11 . Eight week body weight of males ND, $\mathrm{H}$ and NN birds were expected to increase by 64.7, 46.1 and $43.9 \mathrm{~g}$, respectively. While in females ND, $\mathrm{H}$ and NN birds, the expected responses were $21.5,27.9$ and $10.7 \mathrm{~g}$, respectively.
\end{abstract}

(Key words: Native chicken, performance, genotype, generation)

\section{Introduction}

The need to produce more animal protein in the country has become increasingly urgent in view of the ever rising population. Indigenous chickens are widely distributed in rural and peri-urban where they play the important role of income generation and food production (Thornton et al., 2002; Moreki et al., 2010). Eggs and meat from indigenous chicken contribute to the protein nutrition of various household in the country. For improving performance of indigenous chickens and hence improved productivity, interventions to improve their genetic potential through appropriate breeding programs are inevitable. Breeding programs involving selection within indigenous chickens have been suggested as the best way of improving their genetic potential (Lwelamira, 2012). The knowledge of performance of economic traits in chicken is important for the formulation of breeding plans for further improvement in production traits. Growth and production traits of a bird indicate its genetic constitution and adaptation with respect to the specific environment (Ahmed and Singh, 2007). The exploitation of genetically diverse stocks for improving economic traits, such as body weights and annual egg production is one of the approaches in the breeding programs of chickens. Therefore, the present study was undertaken to evaluate the performances of 3 genotypes of indigenous chicken under intensive management system.

*Corresponding author: shakila_blri@yahoo.com

Bang. J. Livs. Res. Special Vol. 21-25, 2018: P. 153-158, ISSN 1022-3851 


\section{Materials and Methods}

\section{Production of fifth generation (G5) from fourth generation (G4)}

The experiment was conducted in BLRI poultry research farm during the year 2014 to 2015. A total of 1128-day-old chicks comprising of 3 types of indigenous chicken namely Naked Neck (NN-268), Hilly (H-353) and Non-descript Deshi (ND-507) were hatched in one batch to produce fifth generation (G5). Progeny were wing banded and reared separately according to genotypes.

\section{Birds rearing and data collection}

The birds were housed in an open sided semi gable type roof with concrete floor. Fences were made from galvanizing wire net. The adult birds were reared in a cage individually. Each cage was equipped with an individual feeder and drinker. All the birds were reared in a natural-ventilated poultry house and a $16 \mathrm{~h}$ photoperiod with $12 \mathrm{~h}$ sunlight and $4 \mathrm{~h}$ artificial lights. The ingredients used to prepare diet were maize, rice polish, soya bean meal, protein concentrates and synthetic methionine and lysine. A premix containing trace minerals and vitamins were mixed with all diets. Also, common salt and Di-calcium Phosphate (DCP) were added to the diets. Concentrate mixtures that contain 20.06\% Crude Protein \& $2908 \mathrm{Kcal} \mathrm{ME} / \mathrm{kg} \mathrm{DM}$; $18.13 \%$ Crude Protein \& $2904 \mathrm{Kcal} \mathrm{ME} / \mathrm{kg}$ DM and $16.33 \%$ Crude Protein \& 2845 Kcal $\mathrm{ME} / \mathrm{kg} \mathrm{DM}$ were provided twice daily in the morning and evening during brooding, growing and laying period, respectively. Water was also provided adlibitum twice daily in the morning and evening. Drinkers were cleaned everyday where feeders were cleaned twice in a week. Refusals of the feed were measured everyday in the morning. Performance of NN, $\mathrm{H}$ and ND were evaluated by measuring their i) laying performance (hen-day egg production, hen-house egg production, egg weight and age at first laying), ii) hatching performance (fertility and hatchability) and iii) growth performance (weekly body weight and mortality).

\section{Selection and mating plan of fifth generation (G5)}

i) Breeding design and experimental birds

Experimental birds (Fifth Generation - G5):

\begin{tabular}{|c|c|c|c|c|c|c|c|}
\hline \multirow[t]{2}{*}{$\begin{array}{l}\text { Name of } \\
\text { genotype }\end{array}$} & \multirow[t]{2}{*}{ Sex } & \multirow{2}{*}{$\begin{array}{l}\text { No. of } \\
\text { day } \\
\text { old } \\
\text { chicks }\end{array}$} & \multicolumn{2}{|c|}{$\begin{array}{l}\text { No. of growing } \\
\text { chicks }\end{array}$} & \multirow{2}{*}{$\begin{array}{l}\text { No. } \\
\text { of } \\
\text { adult } \\
\text { birds }\end{array}$} & \multicolumn{2}{|c|}{ No. of selected bird } \\
\hline & & & $\begin{array}{l}8 \\
\text { wks }\end{array}$ & $\begin{array}{l}16 \\
\text { wks. }\end{array}$ & & Selected & Spare \\
\hline \multirow[t]{2}{*}{$\mathrm{NN}$} & Male & 268 & 45 & 40 & 40 & 10 & 5 \\
\hline & Female & & 115 & 100 & 100 & 50 & 10 \\
\hline \multirow[t]{2}{*}{$\mathrm{H}$} & Male & 353 & 45 & 40 & 40 & 10 & 5 \\
\hline & Female & & 115 & 100 & 100 & 50 & 10 \\
\hline \multirow[t]{2}{*}{ ND } & Male & 507 & 85 & 80 & 80 & 20 & 10 \\
\hline & Female & & 230 & 200 & 200 & 100 & 20 \\
\hline
\end{tabular}




\section{i i) Selection objectives}

The selection objectives of the study were to improve the egg production and / or growth rate of Indigenous chicken depending on the genotype of birds. Improvement target of egg weight is to increase by $1 \mathrm{~g}$, improvement target of egg production rate is to increase by $2 \%$ per generation and improvement target of growth rate is to increase by $20 \mathrm{~g}$ per generation.

\section{iii) Selection criteria}

In each generation, selection was practiced in two stages. Firstly, at 8 weeks of age, selection was performed on the basis of body weight and physical appearance and secondly, at 40 weeks of age on the basis of an index comprising the following parameters.

* Age at first egg (days)

* Body weight ( $\mathrm{g}$ ) at 40 weeks of age

* Egg production (\%) (168-280 days)

$*$ Egg Weight (g) at 40 weeks of age

\section{iv) Mating plan}

In flocks of all generations, selected males and females were mated assortatively with a maximum male: female ratio of 1: 5 using artificial insemination avoiding mating among close relatives.

\section{Statistical analysis}

All recorded data were analyzed by Generalized Linear Model (GLM) procedure using SPSS 11.5 for Windows (SPSS, 1998). For all statistical purposes the theory of Snedecor and Cochran (1989) were followed. The present data used in the study were from three different genotypes and the structures of data were unbalanced. The number of birds varied from class to class and subclass to subclass. Hence, it confirmed the characteristics of a non-orthogonal factorial experiment. To take this situation into account the data were analyzed by factorial arrangement in a CRD by General linear Model (GLM) Univariate Procedure in SPSS Computer Program.

The following general linear statistical model was used to analyze the different parameters:

$\mathbf{Y i j}=\boldsymbol{\mu}+\mathbf{g i}+\mathbf{e i j}$, where, Yij is the dependent variable of the experiment; $\mu$ is the overall mean; gi is the effect of ith genotype ( $\mathrm{i}=1-3)$; eij is the error term specific to each record.

\section{Prediction of expected selection response}

Expected selection response in three types of indigenous chicken for body weight at 8 weeks was estimated using the following equation (Falconer, 1981).

$\mathrm{R}=\mathrm{h}^{2} \times \mathrm{S}$

Where,

$\mathrm{R}=$ Expected response in mass selection

$\mathrm{h}^{2}=$ heritability, $\mathrm{h}^{2}$ for BW at 8 weeks of age

$\mathrm{S}=$ Selection differential

\section{Results and Discussion}

\section{Body weight}

The average body weights of ND, $\mathrm{H}$ and NN were $979.29 \pm 11.58, \quad 1250.71 \pm 27.71$ and $940.13 \pm 17.43 \mathrm{~g}$, respectively at 12 weeks (Table 1). The 12th week body weight was significantly $(p<0.001)$ affected by genotype. Significantly $(p<0.001)$ highest body weight was observed in $\mathrm{H}$ genotype $(1502.54 \pm 36.81 \mathrm{~g})$ compared to ND $(1300.39 \pm 20.26 \mathrm{~g})$ and $\mathrm{NN}$ $(1213.39 \pm 24.96 \mathrm{~g})$ genotypes at 16 th weeks of age. The gap narrowed at 12th and 16th week weight with $\mathrm{H}$ and $\mathrm{NN}$ genotypes by 
310.58 and $289.15 \mathrm{~g}$, respectively. Faruque (2016) observed that body weight of ND, H, $\mathrm{NN}$ at 12 and 16 weeks of age averaged 778, 921, 770 and 1071, 1282, 1036g; respectively, those were much lower than the present findings. Islam and Nishibori (2009) reported the body weight of Bangladeshi NN to be $1214 \mathrm{~g}$ at 16 weeks of age. The NN birds of the present study weighed $1213 \mathrm{~g}$ at the same age.
The estimated age at 1st egg of ND, $\mathrm{H}$ and NN were 159.95, 161.95 and 152.79 days; respectively. Hilly genotype started laying eggs at a higher age (161.95 days) compared to NN genotype (152.79 days) in G5 generation. The average age at first egg of NN (152.79 days) was 9.16 days earlier than that of $\mathrm{H}$ (161.95 days). The average age at first egg of $\mathrm{NN}$ (152.79 days) was comparable to that of NN (152.7 days)

Table 1. Body weight ofindigenous chicken up to 16 weeks of age

\begin{tabular}{lcccc}
\hline Parameter & \multicolumn{3}{c}{ Genotype } & Level of \\
\cline { 2 - 5 } & ND (Mean \pm SE) & H (Mean \pm SE) & NN (Mean \pm SE) & sig. \\
\hline $12^{\text {th }}$ week weight (g) & $979.29^{\mathrm{b}} \pm 11.58(315)$ & $1250.71^{\mathrm{a}} \pm 27.71(155)$ & $940.13^{\mathrm{b}} \pm 17.43(139)$ & $\mathrm{p}<0.001$ \\
$16^{\text {th }}$ week weight (g) & $1300.39^{\mathrm{b}} \pm 20.26(208)$ & $1502.54^{\mathrm{a}} \pm 36.81(140)$ & $1213.39^{\mathrm{c}} \pm 24.96(137)$ & $\mathrm{p}<0.001$
\end{tabular}

$\mathrm{ND}=$ Non-descript Deshi; $\mathrm{H}=\mathrm{Hilly}$; NN=Naked Neck; figures in the parentheses indicate the number of observations; least squares means without a common superscript along the row within a factor differed significantly $(\mathrm{p}<0.001)$.

\section{Mortality}

$\mathrm{NN}$ genotype $(2.92 \%)$ had significantly $(\chi 2=$ 9.023; $\mathrm{p}<0.05)$ higher chick mortality than ND $(0.68 \%)$ and $\mathrm{H}(2.08 \%)$ at $0-8$ weeks of age (Table 2). The mortality rate was slightly lower in NN than ND and $\mathrm{H}$ chicken (Khatun et al., 2005). This finding is not similar to our present findings. Better survivability was observed in ND genotype in this study. The mortality rate of indigenous chickens in brooding period (0-8 weeks) was 3.10, 4.05 and $2.92 \%$, respectively under intensive system of rearing (Faruque et al., 2015). Khan (2008) reported 70\% mortality of indigenous chickens under free range management system. reported by Faruque (2016). Feed consumption from 9 to 16 weeks (Table 3) showed that there was significant $(\mathrm{p}<0.001)$ variation in feed intake among the Indigenous Chickens. At the age of 16 weeks, the lowest $(62.96 \mathrm{~g})$ and highest $(83.46 \mathrm{~g})$ daily feed intake were recorded for $\mathrm{ND}$ and $\mathrm{H}$ genotypes, respectively. The effect of genotype on HDEP (\%) of Indigenous Chicken was presented in Table 3. Hen-day egg production (HDEP \%) observed in the present study were affected significantly $(\mathrm{p}<0.001)$ by genotype. In this study, the average $\mathrm{HDEP} \%$ of $\mathrm{ND}, \mathrm{H}$ and $\mathrm{NN}$ were found to be $38.44 \pm 2.18,30.43 \pm 2.10$ and $41.95 \pm 2.11$, respectively (Table 3 ).

Table 2. Effect of genotype on chick mortality (\%) during 0-8 weeks of age

\begin{tabular}{lccccc}
\hline Genotype & ND & H & NN & $X^{2}(\mathrm{df}=2)$ & P-Value \\
\hline Mortality (\%) & 0.68 & 2.08 & 2.85 & 9.023 & $\mathrm{p}<0.05$ \\
\hline
\end{tabular}

\section{Productive and reproductive performance}

The age at first egg laid was significantly $(\mathrm{p}<0.001)$ affected by genotype (Table 3$)$.
Significant effect of genotype on HDEP\% found in this study confirms with the result of previous report by Miah et al. (2002) who found that breed had significant $(\mathrm{p}<0.05)$ 
Table 3. Productive and reproductive performance of native chicken genotypes

\begin{tabular}{lllll}
\hline Parameter & \multicolumn{2}{c}{ Genotype (Mean \pm SE) } & $\begin{array}{c}\text { Level of } \\
\text { Significance }\end{array}$ \\
\cline { 2 - 5 } & \multicolumn{1}{c}{ ND } & H & NN & Sige at first egg (d) \\
\hline $\begin{array}{l}\text { Feed Intake (9-16 weeks) } \\
\text { (g/b/d) }\end{array}$ & $62.96^{\mathrm{b}} \pm 1.48$ & $83.46^{\mathrm{a}} \pm 1.43$ & $66.94^{\mathrm{b}} \pm 1.41$ & $\mathrm{p}<0.001$ \\
HDEP (21-30 weeks) $(\%)$ & $38.44^{\mathrm{a}} \pm 2.18$ & $30.43^{\mathrm{b}} \pm 2.10$ & $41.95^{\mathrm{a}} \pm 2.11$ & $\mathrm{p}<0.001$
\end{tabular}

Least squares means without a common superscript along the row differed significantly $(\mathrm{p}<0.001)$

effect on hen-day egg production. In this study, the highest HDEP\% was found in NN genotype (41.95) at 21-30 weeks of age. This finding is not in agreement with the finding of Faruque et al. (2010) who found the highest $\mathrm{HDEP} \%$ in ND genotype (38.72) at 23-52 weeks of age. In the previous study reported by Faruque (2016), the average $\mathrm{HDEP} \%$ of ND, $\mathrm{H}$ and $\mathrm{NN}$ were found to be $51.4 \pm 0.4,44.0 \pm 0.4$ and $48.1 \pm 0.4$, respectively at 24-45 weeks of age. This finding is much higher than the present finding.
NN birds, the expected responses were 21.5, 27.9 and $10.7 \mathrm{~g}$, respectively. The response to selection for 8 weeks body weight in male and female for three genotypes (ND, $\mathrm{H}$ and $\mathrm{NN}$ ) were expected to increase and higher in $\mathrm{H}$ genotype than other two genotypes. Faruque (2016) found 8th week body weight of males ND, $\mathrm{H}$ and $\mathrm{NN}$ birds were expected to increase by $52.03,53.98$ and $37.40 \mathrm{~g}$, respectively. While in females ND, $\mathrm{H}$ and NN birds, the expected responses were 20.92, 24.70 and $12.43 \mathrm{~g}$, respectively.

Table 4. Selection differential, selection intensity for 8 weeks body weight $(\mathrm{g})$ in fifth generation (G5) of Native Chicken

\begin{tabular}{cccccccccc}
\hline $\begin{array}{c}\text { Ge } \\
\text { not } \\
\text { ype }\end{array}$ & Sex & Before selection & After selection & $\begin{array}{c}\text { Selection } \\
\text { Differential } \\
\text { (S) (g) }\end{array}$ & $\begin{array}{c}\text { Selection } \\
\text { Intensity (i) }\end{array}$ & $\begin{array}{c}\text { Phenotypic } \\
\text { Standard } \\
\text { Deviation } \\
\text { (SD) }\end{array}$ & $\begin{array}{c}\text { Expected } \\
\text { Response to } \\
\text { Selection } \\
\text { R }\end{array}$ \\
\hline & M & 281 & 650.2 & 85 & 780.0 & 129.8 & 1.13 & 114.7 & 64.7 \\
Z & F & 302 & 525.4 & 230 & 568.5 & 43.1 & 0.42 & 102.5 & 21.5 \\
工 & M & 62 & 844.5 & 30 & 938.9 & 94.4 & 0.88 & 106.8 & 46.1 \\
& F & 135 & 677.4 & 100 & 734.5 & 57.1 & 0.48 & 118.5 & 27.9 \\
Z & M & 121 & 661.5 & 45 & 753.4 & 91.9 & 0.99 & 92.8 & 43.9 \\
\hline
\end{tabular}

\section{Expected response}

As shown in Table 4 that 8 th week body weight of males $\mathrm{ND}, \mathrm{H}$ and $\mathrm{NN}$ birds were expected to increase by $64.7,46.1$ and $43.9 \mathrm{~g}$, respectively. While in females, $\mathrm{ND}, \mathrm{H}$ and

\section{Conclusion}

In conclusion, it may be stated that Hilly chicken genotype can be chosen for meat production and Naked Neck genotype for egg production. For further improvement selection should be continued. 


\section{References}

Ahmed, M. and Singh, P.K. 2007. Estimates of genetic parameters for some economic traits in White Leghorn. Indian Journal of Poultry Science, 42: 311-312.

Faruque, S. 2016. Improvement of economic traits of indigenous chicken in Bangladesh through selective breeding. Ph.D Thesis, Department of Animal Breeding and Genetics, Bangladesh Agricultural University, Mymensingh.

Faruque, S., Afroz, M.A. and Islam, M.S. 2010. Evaluation of response to selection in chicken. International Journal of BioResearch, 1: 01-05.

Faruque, S., Bhuiyan, A.K.F.H., Ali, M.Y., Rahman, M.O.A., Sarker, M.S.K. and Sarker, N. R. 2015. Conservation and improvement of native chicken: Performance of fourth generation. Annual Report, Bangladesh Livestock Research Institute, Savar, Dhaka. http://www.lrrd.org/lrrd22/3/more22055.htm.

Islam, M.A. and Nishibori, M. 2009. Indigenous naked neck chicken: a valuable genetic resource for Bangladesh. World's Poultry Science Journal, 65: 125-138.

Khan, A.G. 2008. Indigenous breed, crossbreds and synthetic hybrids with modified genetic and economic profile for rural family and small scale poultry farming in India. World's Poultry Science Journal, 64:405-415.
Khatun, R., Islam, M.S., Faruque, S., Azmal, S.A. and Uddin, M.S. 2005. Study on the productive and reproductive performance of 3 native genotypes of chicken under intensive management. Journal of Bangladesh Agricultural University, 3:99-104.

Lwelamira, J. 2012. Genotype-Environmental $(\mathrm{G} \times \mathrm{E})$ Interaction for Body Weights for Kuchi Chicken Ecotype of Tanzania reared On-Station and On-Farm. International Journal of Poultry Science, 11 (2):96-102.

Miah, M.S., Islam, M.A. and Ali, M.A. 2002. Growth and egg production performance of exotic pure breeds and crossbreeds chicken. The Bangladesh Veterinarian, 19 (1) :43-47.

Moreki, J.C., Dikeme, R. and Poroga, B. 2010. The role of village poultry in food security and HIV/AIDS mitigation in chobe District of Botswana. Livest. Res. Rural Dev., 22, Article $\neq 5$

Thornton, P.K., Kruska, R.L., Henniger, N., Kristjanson, P.M., Atieno, F., Odero, E.N.E. N. and Ndegwa, T.2002. Mapping poverty and Livestock in Developing World. ILRI, Nairobi, Kenya, pp:124. 